DOI: doi.org/10.21009/IJLECR.042.13

Received: 5 June 2018

Revised: 10 June 2018

Accepted: 14 August 2018

Published: 31 December 2018

\title{
THE PRAXIS OF HONESTY BUILDING AT SMPN 1 PEKANBARU
}

\author{
Ade Prima Rahayu ${ }^{1, \mathrm{a})}$, Darmahusni ${ }^{1, \mathrm{~b})}$, Ratna Dewanti ${ }^{1, \mathrm{c})}$ \\ Department of English, Faculty of Languages and Arts, State University of Jakarta, Jakarta, \\ Indonesia $^{1)}$ \\ adeprima_pb16s2@mahasiswa.unj.ac.id ${ }^{\text {a) }}$, darmahusni@unj.ac.id ${ }^{\text {b) }}$, rdewanti@unj.ac.id ${ }^{\text {c) }}$
}

\begin{abstract}
This study is aimed to investigate the praxis of honesty building in teaching and learning activities at SMPN 1 Pekanbaru. The data of this study were teacher and students activities in English classroom which were gathered by using observation and interview. The results showed that teacher and students have embarked the honesty praxis which is theoretically stated in Kompetensi Inti 2 in 2013 Curriculum by stimulating the aspects of responsibility, trustworthy, and discipline frequently at the main stage. There was a consistency showed by teacher and students in practicing the honesty as presented when the teacher gave instructions to close the book then all students followed it without any disobedience and it explained the concept of praxis is a reflection activity which bring theory into practice. It concludes that English teaching and learning activities at SMPN 1 Pekanbaru have contributed in the praxis of honesty.
\end{abstract}

\section{Keywords: Praxis, Honesty, English Classroom, Junior High School}

Praxis is the process of taking action in practice and mutual relationship between theory and practice (Cowley, 2008, p. 1). In praxis, abstract theorizing is only useful so long as it informs concrete action. Likewise action must be informed by deep thinking and justification.

The action related to educational context brings any issue of national character building. Currently, the issues of national character have become the public attention in Indonesia, such as corruption, violence, vandalism, fights mass, political life is not productive, and so become several topics of discussion. To overcome the issues of national character, various alternative solutions have been proposed such as regulation, legislation, increased efforts to the implementation, and application of the law stronger.

Another alternative to resolve the problem of national character is through education. Education is considered as a preventative solution in its role to build a new generation. As an alternative preventative, education is expected to improve the quality of the nation's youth in various aspects that can reduce the cause of various inequality issues of national character. Zubaedi (2011, p.5) defines character education as a teaching program in schools aimed at developing the character of students by living up the values and beliefs of society as a moral force in their lives through honesty, trustworthiness, discipline and cooperation that emphasizes affective (feeling/attitude) without leaving the rational thinking and skill domains (skill in processing data, expressing opinions and cooperation).

In Indonesia's educational system, character education is not likely a brand new thing. 
There are two subjects that contribute to develop students' moral and values, they are religion and civics education. Unfortunately, those subjects may not significantly contribute in building students' good character because they only emphasize to the knowledge of the values not about how to apply them in the daily life (Kemdiknas, 2010). As the consequence, the students only know all about the values but they do not see the real example of how to implement them in their daily life. Because the result of character education through religion and civics education may have not yet satisfying, the government believed that it should involve all of the subjects. The implementation of it should also be modified in such a way that focus on the students' cognitive, affective and psychomotor development that the character values are not only integrated in all core materials or topics of the lessons but also should facilitate the students to implement them into the learning activities.

As mandated by the Indonesia Minister of National Education and Culture the use of 2013 Curriculum from elementary to senior high level, is focused on character education for the students. By preparing and implementing the character education at school, government expects that positive character of the students can be integrated to their academic competence. Consequently, as English is one of the compulsory subjects at Junior High School level, the implementation of character education of honesty in English language instruction becomes focus of this study.

Multiple studies have examined the positive impacts of building the national character in school. In a study that conducted by Lucas (2009) focused on teachers' perceptions of character education implementation in their school. The researcher found that all twelve teachers interviewed in her study agreed that character education is essential and declared the teachers' responsibility of exhibiting good role models. Teacher modeling appeared to be the main method of character education implementation. One of the teachers indicated how vital character education is for middle school students, in particular, because school is a place for them to develop the sense of belonging in a family-like school climate.

Then, the positive effects of building the good character can be perceived not only by the students and teachers, but also the overall climate of the school, and society. White and Warfa (2011) state teaching students on character and values change the climate of the school. In their study, students reported that learning becomes more fun because the focus remains on the wellbehaved kids and their behaviors rather than to the students who are messing around. The students demonstrating appropriate behaviors then become the norm while students demonstrating inappropriate behaviors do not want to be excluded by others, so they quit the behavior to fit in with the rest of the class. The learning has gone beyond the classroom and out into the real world. In short, it can be said that the character education creates students who are ready to be productive members of society.

Another research conducted by Hudha, Dyah, and Husamah (2014) explains that the implementation of integrated character education in teaching and learning process can be done through some basic activities, namely in the preparation part by incorporating character values developed into syllabus and lesson plan, the implementation of learning is carried out by internalizing the values of the characters in the initial, core, and closing activities, students' character evaluation is done by making attitude indicators to be assessed in the rubric of attitude assessment.

In reference to the implementation of building the character, Fridiyanto \& Khairani (2014) found there are several obstacles and challenges in carrying out the mandate of character education in SMPN 7 Kota Jambi. Time constrains and lack of the teachers' understanding of character education in teaching and learning process, the school management has not actively supported the process of building the character, and the lack of a positive climate and culture in school causes the 
character education process do not run optimally as expected. However, the process character building will be effective when the obstacles and challenges have been overcome by all concerned.

Nowadays, honesty is important to be implemented in school as a representation of national character. Samani and Hariyanto (2012, p.51) declares honest is to state what it is, open, consistent between what is said and done, dare to be true, trustworthy, and not cheating. Another scholar, Koellhoffer (2009, p.27-33) defines types of honesty as academic honesty, integrity, sincerity, scientific honesty, honor, trustworthiness, and sportsmanship. Being honest means able to tell the truth based on facts, not only to other people but also to oneself, and fairly to tell and do things even though confronted by many people. Then, Otten (2002) mentioned some indicators of honesty, such as consistently truthful; never stealing, cheating, misleading, or deceiving; and telling information without distortion or exaggeration. Being honest can also means commit to do the right things, follow the rules, admit mistakes or weaknesses, and accept the consequences.

Based on the definitions explained above, there are some aspects which describe the fundamental meaning of honesty and how the character can be built, such as responsibility, discipline, and trustworthy. Responsibility means things or duty that someone is required to do and there are always consequences behind them. In school context, any action is bound by existing regulations or rules and the rules must be obeyed because there is a punishment for bad behavior and it is interpreted as a concept of discipline. On the other hand, trustworthy is categorized as being able to be relied on to do something or provide what is needed.

In order to see the implementation of honesty in school, there is one particular thing about character building program which proclaimed by Ministry of Education and stated as one of the core competences in 2013 curriculum (KI 2) that is:

"Menghargai dan menghayati perilaku jujur, disiplin, tanggung jawab, peduli (toleransi,

gotong royong), santun, percaya diri, dalam berinteraksi secara efektif dengan lingkungan

sosial dan alam dalam jangkauan pergaulan dan keberadaannya."

The statement above signifies the character building program has been taken seriously and measurably mandated for each educational institution, in this case at Junior High School level. The KI 2 became a school benchmark in executing students' character building integrated with academic content. Honesty, discipline, responsibility, and caring are the core characters to be built and developed to the students through any activities in school.

In 2015, one of public schools in Pekanbaru, SMPN 1 has become the first Junior High School mandated to implement the Curriculum 2013 as its curriculum. The mandate is poured into the school's vision and mission so that it becomes a guide to running educational programs. Several statements related to character building are listed in the school mission, including honesty. The mandate also made SMPN 1 Pekanbaru a pilot project in implementing the 2013 curriculum at the Junior High School level, while other schools were still implementing the 2006 curriculum which was not based on character building. Therefore, the findings from this study are expected to provide information regarding how the honesty praxis at Junior High School level in the English classroom activities.

\section{METHOD}

This study employed a qualitative case study to gain insight into the honesty praxis in school context. Case study are useful when describing the context of study and the extension of particular program or innovation has been implemented (Gay, Mills, \& Airasian, 2012, pp.444-5).

The data for this study was English classroom activities of honesty praxis from teacher and students classroom activities. In qualitative research, samples tend to be small and not necessarily representative of the phenomena under investigation (Gay, Mills, \& Airasian, 2012, p. 118). In choosing the participants, purposeful sampling will used (Creswell, 2012, p. 206). 
To investigate the praxis of cultural literacy in English Language Instruction classroom activity, two instruments were used, observation and interview. The observation was employed to get information of honesty praxis in English classroom at SMPN 1 Pekanbaru in detail and accurately. The observation was done through recording the English teaching and learning process by using GoPro 6 camera. Then, the recorded classroom activities were transcribed to catch what happened in the classroom in detail through dialogue, gesture, instruction, responds.

Further, the interviewed was conducted with open-ended questions and open-ended responses. The use of audio recorder was intended to help the interviewer in gaining the more detailed data during the interview. The data gained from this instrument were in the form of interview notes and audio-recording. The audio recording was transcribed and analyzed. In addition, in order to make the interview clearer and more comfortable, the language used for the questions of the interview was Bahasa Indonesia.

The data is analyzed by using the main concept of this study which was honesty as an attitude or quality of students to be responsible, discipline, and trustworthy (Otten, 2002; Koellhoffer, 2009; and Samani and Hariyanto, 2012) and the concept of praxis as a combination between theory and practice by Cowley $(2008$, p. 1).

\section{RESULTS AND DISCUSSIONS}

This part explains how English classroom activities present the aspect of honesty when teacher and students of SMPN 1 Pekanbaru practiced it in the classroom. The aspects being discussed are responsibility, discipline, and trustworthy which described the honesty praxis. The English teacher enclosed character building of honesty in all stages (preliminary, main, and closure) of teaching and learning process based on the three aspect of honesty. The explanation based on each class observation that has been done previously.

In preliminary stage, the session opened with praying together leaded by the class leader without being told beforehand. The class leader knew and being responsible for his duty to prepare the class as soon as the teacher entered the class and reached the desk. After that, the teacher greetings the students and fairly started to check the attendance list if there was students who are unable to attend the class before entering the main stage. The teacher obeyed the rules by completing the administrative requirements before starting the class. As indicated by Koellhoffer (2009, p.27-33) that an attitude of obeying the rules was one of the indicator of honesty.

Meanwhile, at the main stage several aspects dominated the process of building the character of honesty, such as being disciplined, responsible, and trustworthy. However, discipline was the most practiced if compared with others at this stage. Discipline which represented through the utterance, "Me, Mam.. Me! (All students raise their hand)" or "Yaahh...(Some students disappointed and raised down their hand)" when they were not being picked by the teacher. The utterances indicated students know their role in learning process which actively participate in classroom activities and executed that role as mention by Koellhoffer (2009, p.27-33). Students eagerly raised their hand and showed the motivation in following the learning process.

In consequence, the students who raised their hand should answered teacher's question in the chosen order by coming forward and writing the answer on the board or demonstrating the dialogue of the topic being discussed in front of the class. The students' responses were manifestation of honesty praxis in classroom from the aspect of responsibility. The students learn to complete what they started by answering the question based on what they have in mind as the consequence of raising their hand consciously and this action was one of the elements of honesty praxis stated by Otten (2002). At this point, the teacher helped the students to actualize themselves through the implementation of honesty and convinced them that being responsible is necessary. The teacher encourages students to be brave enough to present the answers even though the answer 
may be wrong through an order "Maju ya yang udah Mam panggil tadi, tulis dulu jawabannya. Nanti kita periksa sama-sama.". When the teacher gave instruction to come forward based on the order and the students followed the instruction without cheating, it showed consistency of honesty praxis between teacher and students as stated by Cowley $(2008$, p. 1) that praxis is combination and mutual relationship between theory and practice which applied in natural way.

In the classroom, the teacher can also run her part as a role model in building students' character. One of the efforts was the teacher give a response when the students break the rule. The teacher warned the students by saying "Next time bring all books you need based on the subject of the day, ok?" and "Don't forget to bring the books." The warnings signified the process of character building is being run by the teacher since the students notice their teacher's character. By giving warnings, the teacher provided an example how behavior of forgetting brings the textbook was one indication of self-discipline that must be addressed as early as possible. The teacher confirmed the action through this statement,

"Contohnya, ketika ada yang jujur gak bawa buku pelajaran, ya Saya kasih toleransi

dulu satu dua kali. Setelahnya masih gak bawa baru ada hukuman. Jadi mereka dididik

untuk jujur pada diri sendiri, bertanggung jawab, dan berani."

As stated in the interview above, the teacher paid much attention to the students who did not bring the textbook by warning them at least twice and then gave punishment at the end. On the other hand, the teacher gave a compliment to the students when they brought the textbook because they obey the rules and being disciplined, such as "Good, bring any books you want to use in every school day". The attitude to appreciate others' efforts was the message that the teacher wanted to share to the students.

Then, at the closure stage, there were only two activities indicated honesty aspects, such as when the students submitted the task on time and when a student erased the white board as soon as the subject shifting from one to another to show their responsibility aspect. There were few chances for both students and teacher to show the implementation of honesty at the closure stage because the teacher used that stage only to summarize the learning material presented on the main stage before closing the meeting on that day.

Nevertheless, the biggest part of honesty praxis in classroom was indeed located at the main stage. One of the keys to build the character of honesty in classroom is to create two ways communication between teacher and students. Moreover, the interaction between teacher and students or among students constructed supportive learning atmosphere in the classroom. The interactions engage the honesty praxis indirectly and this process will continuously become a character. At the main stage, the teacher has plenty of time to explore the ways to deliver the topic and facilitate the honesty praxis by giving quick question and answer, repeating the word or sentence, and having exercises. Any responses from the students towards teacher's questions or instructions showed there was a consistency of honesty praxis in English classroom activities at SMPN 1 Pekanbaru.

\section{CONCLUSION}

In conclusion, the praxis of honesty building at SMPN 1 Pekanbaru was the implementation of the second core competences (KI 2) in Curriculum 2013. Theoretically the building or development of honesty listed in the Curriculum 2013 and practically implemented in classroom activities. In English classroom activities, from the classroom observations honesty praxis was mostly presented at the main stage as there were much time for teacher to explore the activities by promoting two ways of communication and making interaction as well as delivering the learning material. As long as teacher created the interaction during teaching and learning process, students had lots of opportunities to express their character of honesty and the interaction mostly happened 
at the main stage. Praxis is a combination between theory and practice which implied in this study by the interaction between teacher and students related to the implementation of honesty which based on KI 2 as the grand concept of character building in 2013 Curriculum for Junior High School. There was a consistency showed by teacher and students in practicing the honesty as presented when the teacher gave instructions to close the book then all students followed it without any disobedience and it explained the concept of praxis is a reflection activity which bring theory into practice. The consistency indicated the honesty praxis in classroom activities at SMPN 1 Pekanbaru achieved its target because both teacher and students realized and performed it.

\section{REFERENCES}

Creswell, J. W. (2012). Educational Research: Planning, Conducting, and Evaluating Quantitative and Qualitative Research. Educational Research, 4. https://doi.org/10.1017/CBO9781107415324.004

Cowley, N. (2008). What is Praxis? Discussed in relation to Hegel, Marx, Nietzsche and Sartre. Te Kura Kete Aronui, Volume Fou. Retrieved on 15 July, 2018, from http://www.waikato.ac.nz/_data/assets/pdf_file/0005/149261/NatalieCowley.pdf

Fridiyanto and Khayrani, M. (2014). Implementasi Pendidikan Karakter di SMPN 7 Kota Jambi. Journal Al-Irsyad, 7: 99-112.

Gay, L. R., Mills, G. E., and Airasian, P. (2012). Educational research: Competencies for analysis and applications. Pearson.

Hudha, A.M., Dyah, W.E., and Husamah. (2014). Character Education Model in Mathematics and Natural Sciences Learning at Muhammadiyah Junior High School. International Journal of Education, Learning \& Development, 2(4): 33-47.

Kemdiknas. (2010). Kerangka Acuan Pendidikan Karakter Tahun Anggaran 2010. Jakarta.

Koellhoffer, T. (2009). Character Education: Being Fair and Honest. United States: Chelsea House.

Lucas, L. (2008). https://search.proquest.com/docview/305028586/4FC7FB833A4E4568PQ/1

Otten, E,T. (2002). Developing Character through Literature. Indiana: The Family Learning Association.

Samani, M and Hariyanto. (2012). Pendidikan Karakter: Konsep dan Model. Bandung: Remaja Rosdakarya.

White, R., and Warfa, N. (2011). Building Schools of Character - A Case-study Investigation of Character Education's Impact on School Climate, Pupil Behavior, and Curriculum Delivery. Journal of Applied Social Psychology, 4(1): 1-15.

Zubaedi. (2011). Desain Pendidikan Karakter Konsepsi dan Aplikasinya dalam Lembaga Pendidikan. Jakarta: Kencana. 